\title{
PRDX4 wt Allele
}

National Cancer Institute

\section{Source}

National Cancer Institute. PRDX4 wt Allele. NCI Thesaurus. Code C116656.

Human PRDX4 wild-type allele is located in the vicinity of Xp22.11 and is approximately 22 $\mathrm{kb}$ in length. This allele, which encodes peroxiredoxin- 4 protein, is involved in the regulation of both nuclear factor NF-kappa-B transcription factor activity and cellular redox. 